\title{
Europeanisation of Private Law
}

When, in the 1990s the debate arose on the creation of a European Civil Code and more and more academics jumped on the moving train of European private law, few could have imagined the richness of the field these days. No longer do we generally aspire to codify private law in the European Union in a Nation-State-fashion. Instead, we speak about governance of private law in the European Union. Whether this is multi-level governance, self-governance, or Member-State-led governance no longer matters.

Some researchers follow a pluralist perspective in which they cherish diversity of law, some follow a Europeanist view, in which they seek more uniformity in either the approach or the results this approach leads to. Although there is some tension between these various perspectives, both are intrigued by the process of Europeanisation.

Europeanisation, or in legal terms, the effect of EU law on the national legal orders of the Member States and vice versa, is increasingly receiving more attention. This does not only apply to political scientists, but certainly also to lawyers, that have long adopted the terminology of top-down and bottom-up harmonisation. In European political science this is paralleled by the downloading/uploading dichotomy.

Private law, or the law that relates to legal acts taken by private individuals or companies, perhaps as a surprise to some, is very national in nature. With the rise of the Nation State in the $19^{\text {th }}$ century, each new country set forth its own rules of private law, most notably contract and property law. For some, for example Germany, the publication and entry into force of a common private law, led to a unified country where previously several Germanic states had co-existed. The analogy to the European Union and the need for 'nation building' is easily made.

Ever since the 1980s the European Commission has been working on the creation of rules relating to contract law for the internal market. This internal market, in which there is freedom of movement of goods, persons, services and capital, as well as a uniform system of anti-trust (competition) law, covers all national markets of the Member States. The effect of this EU body of rules, also sometimes held to be the European economic constitution, on national law is becoming more and more apparent. Through the work of the European Commission a body of private law rules has come into being, especially 
in the area of consumer protection (the EU consumer acquis). Through the work of the Court of Justice of the European Union increasingly the effect of the consumer acquis on the national law of the Member States, as well as the effect of the European economic constitution on the national law of the Member States has become apparent.

In law schools the attention to European private law has increased to such an extent that now courses and even full degrees in European private law are offered. Especially at Maastricht University, a relatively large group of specialists have gathered in the Maastricht European Private Law Institute (M-EPLI). Since 2010, groups of students in the maRBLe for Excellence project have been working on selected issues of European Private law. Although originally restricted to contract law, soon the scope of research was broadened to also include areas of property law, tort law and general issues of law. This has very much enriched the work and students have immensely benefitted from each others work.

From April 2013 to the end of June 2013 the current group of authors worked on the Maastricht Project of European Private Law, as the maRBLe for Excellence project is named. With various visits to Brussels, the group of authors engaged with Brussels-based stakeholders to test some of their ideas and presented their research results at the end of June in a full day student-organised seminar at the UM Campus Brussels.

The results of the work are presented in this volume. A word of warm thanks goes out to all that have contributed to this issue, in particular to the students who worked so hard to present their views in the most optimal manner.

Brussels, 10 September 2013

Dr. Bram Akkermans LL.M.

Project Coordinator 